\title{
ESTIMATES OF GENETIC PARAMETERS USING RELM/BLUP FOR INTRA- POPULATIONAL GENETIC BREEDING OF Platonia insignis Mart. ${ }^{1}$
}

\author{
Maria Clideana Cabral Maia ${ }^{2 *}$, Luciano Medina Macedo ${ }^{3}$, Lúcio Flavo Lopes Vasconcelos ${ }^{2}$, João Pedro \\ Alves Aquino ${ }^{2}$, Luís Cláudio Oliveira ${ }^{4}$ and Marcos Deon Vilela Resende ${ }^{5}$
}

\footnotetext{
${ }^{1}$ Received on 01.05.2014 accepted for publication on 03.03.2016.

${ }^{2}$ Embrapa Meio Norte,Teresina, PI - Brasil. E-mail:<clideana.maia@embrapa.br>, <lucio.vasconcelos@embrapa.br>and $<$ joaopedro_138@hotmail.com>.

${ }^{3}$ Universidade Federal do Paraná, Universidade Federal do Paraná, Curitiba, PR - Brasil. E-mail: <medina.ppgebb@gmail.com>.

${ }^{4}$ Empresa Brasileira de Pesquisa Agropecuária, Centro de Pesquisa Agroflorestal do Acre, Rio Branco, AC - Brasil. E-mail: $<$ luis.oliveira@embrapa.br>.

${ }^{5}$ Empresa Brasileira de Pesquisa Agropecuária, Centro Nacional de Pesquisa de Florestas, Colombo, PR - Brasil. E-mail: $<$ marcos.deon@gmail.com>.

*Corresponding author.
}

\begin{abstract}
The aim of this study was to estimate genetic parameters to support the selection of bacuri progenies for a first cycle of recurrent selection, using the REML/BLUP (restricted maximum likelihood/ best linear unbiased prediction) procedure to estimate the variance components and genotypic values. Were evaluated twelve variables in a total of 210 fruits from 39 different seed trees, from a field trial with an experimental design of incomplete blocks with clonal replies among subplots. The three variables related with the fruit development (weight, diameter, length) showed strong correlation, and where fruit length showed higher heritability and potential to be used for indirect selection. Among the 39 progenies evaluated in this study, five present potential to compose the next cycle of recurrent selection, due they hold good selection differential either to agrotechnological variables as to development of bacuri fruit.
\end{abstract}

Keywords: Bacuri; Mixed models (REML/BLUP); Selection.

\section{ESTIMATIVAS DE PARÂMETROS GENÉTICOS VIA REML/BLUP PARA O MELHORAMENTO INTRAPOPULACIONAL DE Platonia insignis Mart.}

RESUMO - O objetivo deste estudo foi estimar parâmetros genéticos capazes de subsidiar a seleção de matrizes de bacuri para um primeiro ciclo de seleção recorrente, utilizando o procedimento REML/BLUP (máxima verossimilhança residual / melhor predição linear não viciada) para se estimar os componentes de variância e valores genotípicos. Doze variáveis foram analisadas para um total de 210 frutos pertencentes a 39 diferentes matrizes, em um experimento de campo estabelecido no delineamento de blocos incompletos com réplicas clonais entre subparcelas. As três variáveis relacionadas com o desenvolvimento do fruto (peso, diâmetro e comprimento) apresentaram correlações acentuadas, e dentre estas o comprimento do fruto foi a que apresentou maior herdabilidade e potencial para ser usada na seleção indireta. Entre as 39 matrizes avaliadas neste estudo cinco apresentam potencial para compor o próximo ciclo de seleção recorrente, por apresentarem bom diferencial de seleção tanto para variáveis agrotecnológicas quanto para de desenvolvimento dos frutos do bacuri.

Palavra-chave: Bacuri; Modelo misto (REML/BLUP); Seleção. 


\section{INTRODUCTION}

Bacuri (Platonia insignis MART.) is an Amazonian fruit tree species of large size often present in dense forests, whose center of origin is estimated to be in the state of Pará (NASCIMENTO et al., 2007). The author points out that the occurrence of the species is rare in Amazonian areas liable to floods, being often found from the north of Paraguay, through the savannahs and plains of the Brazilian Midwest to the Piauí state coast, stretching north from the range covering from the state of Amapá to Guyana. The bacuri tree is considered a indigenous species, but it has high economic potential by presenting multiple uses, producing both high quality wood that is very resistant to decay and the fruit in abundance during the fruiting period (MORAES et al., 1994; SOUZA et al., 2000).

It is relatively recent the concept that different species require specific processing, aseptically and frozen techniques for its conservation for a long period (CHITARRA; CHITARRA, 2005), and for this reason, until the last century, most Amazonian fruits had its consumption limited to the period of the harvest and were known only in the regional market (FRAZÃO; HOMMA, 2006). The evolution of food preservation techniques enabled the bacuri fruit to be available for consumption throughout the year and also exported to new consumer markets (FONTENELE et al., 2010; SILVA et al., 2010). In an assessment of tropical fruit sold in Belém city, Shanley (2000) estimated that each year are sold over seven million bacuri fruits, generating an income higher than 1.5 million dollars to producers, distributors and traders involved in this productive chain. In the Piauí state, the fruit of bacuri is mainly used in the manufacture of juices and sweets (NAZARÉ, 2000), while from seeds is possible to extract a type of fat commonly used by native communities for the treatment of various diseases in humans and animals (SANTOS JUNIOR et al., 2010).

The bacuri fruit is considered by the native population as one of the best of the Amazon forest, with the advantage that it can be consumed raw (NASCIMENTO et al., 2007). The beginning of the reproductive period of this species occurs between the months of June and July, shortly after the fall of the tree leaves that leave exposed their reddish pink color flowers, attracting many birds and insects that carry out pollination (SOUZA et al., 2000). The fruit development occurs for about five months, being ready to harvest between November and January (SOUZA et al. 2000).

Bacuri has excellent ability to budding and regeneration, allowing plants with superior genetic potential to be cloned (CARVALHO et al., 2002). In native vegetation areas, most plants of this species comes from seeds and occurs at low densities (between one and five plants per hectare) whereas areas of secondary vegetation in which there had been deforestation before, the remaining roots in the soil easily regenerate and emerge in the presence of light, giving rise to true bacuri groves with densities exceeding hundred plants per hectare (CARVALHO; MULLER, 2007).

The production and marketing of bacuri fruit can be considered good alternatives to combine nature conservation with sustainable development, enabling increased income of small and medium-sized farmers with the conservation of remaining native vegetation (MATOS et al., 2009). Although several authors have already evaluated parameters related to the variability of the bacuri fruit (SOUZA et al., 2001; CARVALHO et al., 2003; FARIAS NETO et al., 2004; ROGEZ, 2004; AGUIAR et al., 2008; SILVA et al., 2009), most of these studies evaluated fruit collected in native populations, which in the absence of experimental structures generated little information relevant to the genetic improvement of this species that is still incipient.

In studies conducted by Farias Neto et al. (2004) and Silva et al. (2009), the most important genetic parameters estimated for the variables evaluated were the repeatability coefficient, which express the maximum amount that the heritability, in the broad sense, can reach, because represents the proportion of phenotypic variance due to genetic differences, jointly with the permanent effects that the genotypes are under within the environment in which the plants were evaluated (CRUZ et al., 2007). The relevant information obtained from these studies on native populations was restricted to the indication of how many phenotypic assessments would be necessary to perform discrimination of agro-technological variables related to the fruit, in accordance with the accuracy desired by the researcher, preventing evaluation of 
a large number of measurements without a significant gain in accuracy, reducing the time and cost of labor demanded to perform these assessments (CRUZ et al., 2004).

To overcome this difficulty in predicting the true values of native species variance components, it has been recommended the simultaneous use of BLUP and REML methods (RESENDE, 2002). The prediction of BLUP assumes knowledge of the values of variance components and, as this is not possible, estimates of these components via REML have been used, both associated with a linear mixed model to more accurately identify genetic materials of superior quality, providing the allocation of part of the variability to the experimental structures in which the evaluated genetic material is found. In addition, the REML procedure, which has non-negativity constraint for the estimates of variance components, leads to more accurate results by the inclusion, beyond the overall average and the experimental error, of fixed and random effects. The consideration of treatment effects as random is essential in genetic development of plants, because then you can do genotypic selection, otherwise the selection is only phenotypic. The approach of treatment effects as random is emphasized by several authors (DUARTE; VENCOVSKY, 2001; PIEPHO et al., 2007; RESENDE; DUARTE, 2007). Thus, the objective of this study was to estimate genetic parameters related to the bacuri fruit and their interrelations, to support the selection of superior progenies and define effective strategies for the improvement of this species in a first recurrent selection cycle, either by conducting controlled crossings or the management of some of these experimental structures.

\section{MATERIALAND METHODS}

The bacuri population evaluated in this study consists of 39 land races (or provenances)originated from areas of natural occurrence of the species in the states of Piauí and Maranhão, from which it was collected young branches that were subsequently used for rootstocks and planted in an experimental area in the city of Teresina, PI. Ten years after the beginning of the experiment, it was collected 210 fruits, obtained by open pollination of the 39 progenies distributed in the experiment of six repetitions in experimental design of incomplete blocks, composed of five plants per plot. The amount evaluated fruits from each tree in each plot varied from 5 to 28 in accordance with the existence of other clonal replicates of the accesses in another experimental plot, being evaluated a minimum of 10 fruits per matrix. It was evaluated twelve parameters among agro-technological variables and variables related to the development of the fruit: V1 - fruit weight (FW, g), V2 - fruit diameter (DF, cm), V3 - fruit length (LF, $\mathrm{cm}), \mathrm{V} 4$ - relation between fruit length and fruit diameter (LF/DF, dimensionless), V5 - skin thickness (ST, mm), V6 - amount of seeds per fruit (AS/F), V7 - pulp content (PC, \% related to the $\mathrm{FW}), \mathrm{V} 8$ - peel content (PC, \% related to the $\mathrm{FW}$ ), V9 - seeds content (SC, \% related to the FW), V10 - total soluble solids content (TSS $={ }^{\circ}$ Brix), V11 - total titratable acidity (TTA, \%) and V12 - relation TSS/TTA (dimensionless).

Initially descriptive statistical parameters of the variables were obtained using the model 105 from the software Selegen REML-BLUP (RESENDE, 2002). The main results obtained in this model are the mean and variance estimates, the type of distribution observed for each of the variables and their correlations in pairs using Pearson's correlation coefficient $\left(r_{x y}\right)$. The correlation of the twelve variables was also evaluated at the level of experimental matrix, that is, from the values estimated from the average of each progeny, obtained after the genetic analysis of the variance components. The significance of the correlations was verified by applying the FDR criterion (False Discovery Ratio - BENJAMINI; HOCHBERG 1995) with a 5\% significance level. Later the significant correlations were put in order and, using the limit of the median as a reference, the correlations were considered low or high magnitude. Additionally, it was also considered stable the correlations that showed significant in both arrays as individual levels. The formula used by FDR criterion is given by: $F D R_{(\alpha i-j)}=\left(\frac{n_{i}}{n_{j}}\right)^{*} \alpha, F D R_{(\alpha i-j)}=\left(\frac{n_{i}}{n_{j}}\right) . \alpha$, which:

$\alpha=$ confidence level used in the test;

$\alpha_{i-j}=$ critical value of the test for the variables ordered from $\mathrm{i}$ to $\mathrm{j}$;

$\mathrm{n}_{\mathrm{i}}=$ order number of the variable $\mathrm{i}$;

$\mathrm{n}_{\mathrm{j}}=$ order number of the last variable tested.

After the transformation of variables with asymmetric distribution using the formula: $\sqrt{x+0,5}$ (where $\mathrm{x}$ is the original value of the variable), the data were analyzed in Selegen-REML-BLUP program

Revista Árvore, Viçosa-MG, v.40, n.3, p.561-573, 2016 
(RESENDE, 2002) making use of the model 6, destined to the evaluation of data of half-sibs progenies in experimental design of incomplete blocks, with several observations per plots in a single harvest period. Obtaining estimators and predictors in mixed models was performed by iterative processes, whose initial value provided for the heritability was equal to 0.10 , as suggested by Resende (2007). The additive genetic effects were obtained through the use of the additive genetic parentage matrix (A), assuming the parentage of half-siblings among individuals within each open pollinated progeny. This is appropriate, since the species is preferentially allogamous due presenting sporophytic self-incompatibility that restricts its auto fertilization (MAUÉS et al., 1996). The linear mixed model used full modeling (univariate additive model, in incomplete blocks) is given by: $\mathrm{y}=\mathrm{Xb}+\mathrm{Za}+\mathrm{Wc}+\mathrm{H} \partial+e$, in which:

$\cdot \mathrm{y}, \mathrm{b}, \mathrm{a}, \mathrm{c}, \partial$ and $e$ : they are data vectors, of the effects of repetitions (fixed - b), of the effects of additive genetic (random - a), of the effects of portions (random - c), of the effects of blocks within the repetitions (random $-\partial$ ) and of errors (random - e), respectively.

$\cdot \mathrm{X}, \mathrm{Z}, \mathrm{W}$ and $\mathrm{H}$ : are the incidence matrices for the vectors $b$, a, c and $\partial$ respectively.

It was later verified the efficiency of the selection process for the pulp content and TSS/TTA relation variables by comparing the genetic gains predicted by SELEGEN program with the gains for these same variables via indirect selection for traits related to fruit development. It is important to stress that these two agro-technological variables are very relevant both for the production of food derived as for fresh fruit consumption. This simulation of genetic gains was performed using a 5\% selection intensity, that in the level of individuals corresponds to the ten best individuals in a sample of 210 fruits, and, in the level of families, to the ten best fruits in the top two progenies for the variables that were simulation objects.

\section{RESULTS}

Using the FDR criterion at the level of individuals, it was considered as significant the correlations with values above $20 \%$ (Table 1 ). According to the median threshold, it was considered to be of low magnitude the correlation with values between $20 \%$ and $39 \%$, and as high magnitude the correlations with values above $40 \%$. In general, at the level of progenies (lower diagonal), it was observed a greater number of significant correlations than at the level of individuals (upper diagonal), while none of the significant correlations involving the titratable acidity variables (TA) and its relation with the soluble solids (TSS/TA) presented stable for the two data sets.

The most significant correlations were observed both at individuals level as progenies level for the variables related to fruit growth, in particular between the fruit weight and diameter $\left(r_{x y}>0,8\right)$. The fruit weight variable also showed stable positive correlations with the variables: length of the fruit, skin thickness, number of seeds per fruit and total soluble solids content. In

Table 1 - Genetic correlations values among the twelve variables evaluated in the experiment. Upper diagonal express the values at individual levels and at lower diagonal represents values of average's mother-trees.

Tabela 1 - Coeficientes de correlações genética entre as doze variáveis analisadas no experimento. Na diagonal superior se encontram os valores obtidos em nivel de indivíduos e na diagonal inferior os valores obtidos a partir das médias das progênies de cada matriz.

\begin{tabular}{lcccccccccccc}
\hline \multicolumn{1}{c}{ Variables } & V1 & V2 & V3 & V4 & V5 & V6 & V7 & V8 & V9 & V10 & V11 & V12 \\
\hline V1-FW (g) & - & $\mathbf{0 , 9 1}$ & $\mathbf{0 , 7 1}$ & $-0,15$ & $\mathbf{0 , 6 9}$ & $\mathbf{0 , 2 8}$ & $-0,01$ & $-0,10$ & $-0,17$ & $\mathbf{0 , 3 8}$ & 0,17 & $\mathbf{0 , 3 0}$ \\
V2-DF (cm) & $\mathbf{0 , 8 2}$ & - & $\mathbf{0 , 6 1}$ & $\mathbf{- 0 , 3 9}$ & 0,16 & $\mathbf{0 , 2 3}$ & 0,02 & $\mathbf{- 0 , 2 3}$ & $-0,17$ & $\mathbf{0 , 3 6}$ & 0,17 & 0,05 \\
V3-LF (cm) & $\mathbf{0 , 5 4}$ & $\mathbf{0 , 3 9}$ & - & $\mathbf{0 , 4 8}$ & $\mathbf{0 , 5 6}$ & 0,09 & $-0,17$ & 0,02 & $-0,08$ & $\mathbf{0 , 2 5}$ & $-0,01$ & 0,08 \\
V4-LF/DF & $-0,10$ & $\mathbf{- 0 , 4 3}$ & $\mathbf{0 , 6 0}$ & - & $-0,02$ & $-0,13$ & $\mathbf{- 0 , 2 0}$ & $\mathbf{0 , 3 1}$ & 0,03 & $-0,09$ & $-0,15$ & 0,04 \\
V5-ST (mm) & $\mathbf{0 , 5 4}$ & $\mathbf{0 , 4 8}$ & $\mathbf{0 , 4 9}$ & 0,00 & - & $-0,15$ & $\mathbf{- 0 , 4 6}$ & $\mathbf{0 , 4 2}$ & $-0,12$ & 0,19 & 0,10 & $-0,01$ \\
V6-AS/F & $\mathbf{0 , 5 4}$ & $\mathbf{0 , 6 1}$ & $\mathbf{0 , 3 4}$ & $\mathbf{- 0 , 2 2}$ & 0,02 & - & $\mathbf{0 , 3 7}$ & $\mathbf{- 0 , 3 6}$ & $-0,06$ & 0,12 & $\mathbf{0 , 2 4}$ & 0,02 \\
V7-PC (\%FW) & 0,12 & 0,17 & $-0,18$ & $\mathbf{- 0 , 2 7}$ & $\mathbf{- 0 , 5 5}$ & $\mathbf{0 , 6 1}$ & - & $\mathbf{- 0 , 6 5}$ & $\mathbf{- 0 , 3 4}$ & 0,09 & 0,07 & 0,04 \\
V8-PC (\%FW) & $-0,12$ & $-0,18$ & 0,09 & $\mathbf{0 , 2 4}$ & $\mathbf{0 , 5 6}$ & $\mathbf{- 0 , 6 6}$ & $\mathbf{- 0 , 8 6}$ & - & $\mathbf{- 0 , 2 4}$ & $-0,13$ & 0,03 & $-0,02$ \\
V9-SC (\%FW) & 0,13 & $\mathbf{0 , 2 3}$ & 0,14 & $-0,15$ & $-0,10$ & $\mathbf{0 , 4 3}$ & $\mathbf{0 , 2 0}$ & $\mathbf{- 0 , 5 9}$ & - & $\mathbf{- 0 , 2 5}$ & $-0,17$ & 0,15 \\
V10-TSS & $\mathbf{0 , 5 3}$ & $\mathbf{0 , 4 0}$ & $\mathbf{0 , 4 2}$ & $-0,03$ & $\mathbf{0 , 4 1}$ & $\mathbf{0 , 3 9}$ & $-0,15$ & $-0,10$ & $\mathbf{0 , 4 2}$ & - & 0,09 & $\mathbf{0 , 3 2}$ \\
V11-TTA & 0,12 & 0,11 & $\mathbf{0 , 2 0}$ & 0,14 & $\mathbf{0 , 3 8}$ & $-0,08$ & $\mathbf{- 0 , 3 8}$ & $\mathbf{0 , 4 0}$ & $-0,04$ & $-0,01$ & - & $\mathbf{- 0 , 4 7}$ \\
V12-TSS/TTA & $-0,10$ & $-0,10$ & $\mathbf{0 , 3 1}$ & $\mathbf{0 , 3 1}$ & 0,10 & 0,03 & $\mathbf{- 0 , 2 9}$ & 0,13 & 0,18 & 0,16 & 0,01 & - \\
\hline
\end{tabular}

Significant correlations (above $20 \%$ ) highlighted in bold. 
addition, the length of the fruit that was positively correlated with the diameter of the fruit in different intensities for the two sets of data also showed stable and positive correlations with the variables: the relation between the length and diameter of the fruit (LF/DF), peel thickness and total soluble solids content. However, the correlations between the length and diameter (LF/ DF) and the total soluble solids content were not significant in the two levels of the analysis.

Regarding the stability of the other agrotechnological variables correlations, pulp and peel content showed stable correlations with the following variables: number of seeds per fruit, peel thickness and ratio of length and diameter of the fruit (LF/DF), and those that were positive for pulp content was negative for peel content and vice versa. The peel content also showed stable and negative correlation with pulp content and with the seed content, although varying intensities between the two levels of analysis. Only the seed content showed significant and contrasting correlations between the two data sets, being positive in the progenies level and negative in individual level for pulp and total soluble solids contents.

Regarding the type of distribution, five variables (fruit weight, number of seeds per fruit, pulp content, peel content and total soluble solids) had normality of distribution and did not needed to be transformed, while other seven presented asymmetrical distribution and were converted before they had their variance components evaluated (positive asymmetry: fruit length, ratio of length and diameter of the fruit, seed content, titratable acidity (TA) and its relation to the soluble solids content (TSS/TA) ; negative asymmetry: fruit diameter and skin thickness). Even after the transformations made, the coefficient of variation of the experimental error $(\mathrm{CVe} \%)$, which is a measure of the efficiency of the experimental design structures variance uptake, still presented values above $15 \%$ for the variables fruit weight $(20.8 \%)$, number of seeds per fruit (34.2\%) and the ratio between soluble solids content and titratable acidity (33.5\%). The detailed values of the variance components iterative estimates obtained with the SELEGEN program for the 210 fruits coming from 39 bacuri arrays evaluated in this study are shown in Table 2.

The variables pulp content and soluble solids show potential for genetic gains due to their heritability in individuals level presenting high values, identical and
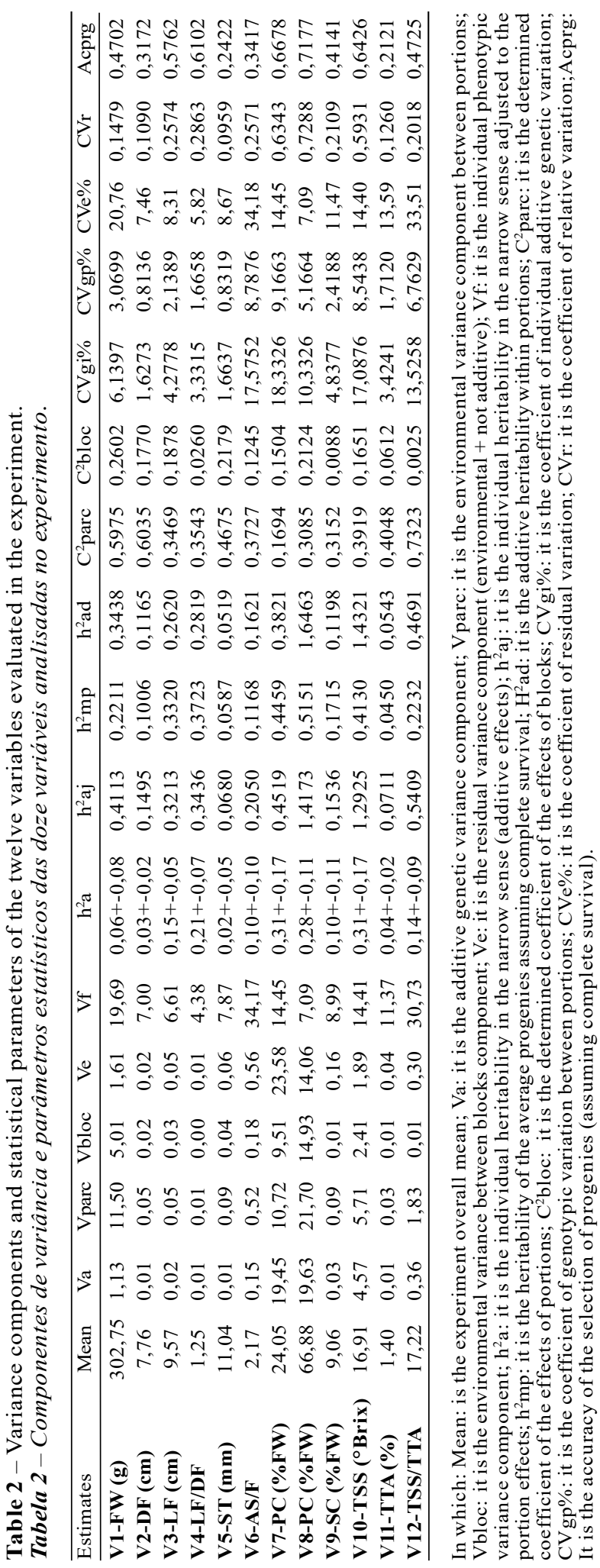
above $30 \%\left(h^{2} a=0,31+/-0,17\right)$ - Table 2 . The relative influence of the experimental structures in the expression of all variables can be visualized in Figure 1. In this chart the Va \% component represents is the variability portion inherent in the genetic part, that, in terms of proportion to the total variability, corresponds to heritability in the narrow sense of the variables evaluated in the experiment. The Vbloc \% component represents the amount of variability captured by the block experimental structures, while the Vparc \% component represents the amount of variability influenced by the experimental structures of plots within blocks. The portion of the variability inherent in other factors which are not detailed in genotypes structures, blocks or plots, is contained within the environmental variance component $(\mathrm{Ve} \%)$, which corresponds to the residual variability not allocated by genetic and experimental structures.

Among the fast measurement of variables related to fruit size, weight and diameter presented low individual additive heritability estimates $\left(h^{2} a\right)$, what based on the amount of their standard deviations, lead these parameters to assume zero heritability. In addition, to these two variables, the experimental component values that represent the effects of plots ( $C^{2}$ parc) were near $60 \%$, confirming that the weight and diameter of the fruit were strongly influenced by the differences of the plots, even though these being located within a experimental area. Although the plots effect $\left(C^{2}\right.$ parc $)$ for the variable length of the fruit being around $35 \%$,

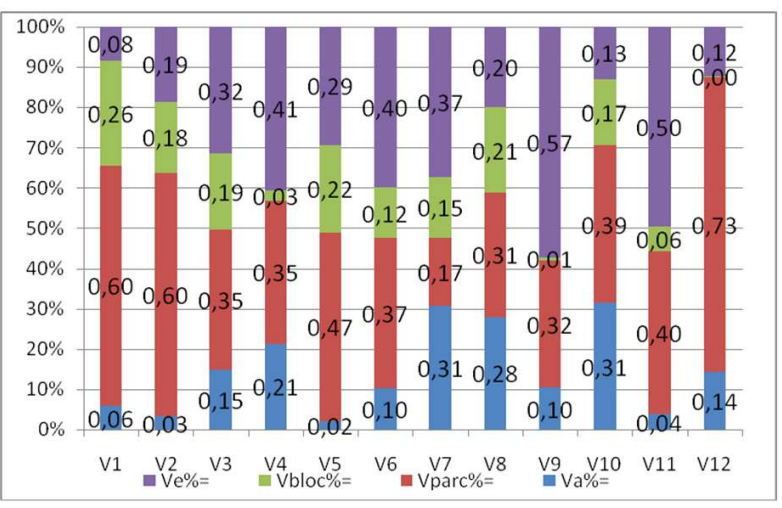

Figure 1 - Relative contribution of the variation sources on the phenotypic expression of the twelve variables evaluated in the trial.

Figura 1 - Contribuição relativa das fontes de variação na expressão fenotípica das doze variáveis avaliadas no experimento. this variable that can also be measured in the field showed additive heritability $\left(h^{2} a\right)$ around $15 \%$. After the adjustment made by the model used for the effects of portion, the weight of the fruit presented individual additive heritability adjusted above $40 \%\left(h^{2} a j=0.4113\right)$ and the length of the fruit above $30 \%\left(h^{2} a j=0.3213\right)$, as for the diameter of the fruit this value was still around $15 \%\left(h^{2} a j=0.1495\right)$.

Other agro-technological variables that also featured zero $h^{2}$ a due to the high amount of standard deviation were: peel thickness $(0.02+-0.05)$, number of seeds per fruit $(0.10+-0.10)$, seeds content $(0.10+-$ $0.11)$ e titratable acidity $(0.04+-0.02)-$ Table 2 . Even after the adjustment for the portion effects, the peel thickness and the titratable acidity still showed small $h^{2} a j$, around $7 \%$. Except for the pulp content where the influence of the portions in the variability of the fruit was only $17 \%$, for all other variables analyzed the influence of this component was pronounced (Figure 1), ranging from $31 \%$ to peel content up to $73 \%$ for the ratio between soluble solids and total titratable acidity (TSS/TA).

As the progenies classification for the three growth variables and two of agro-industrial interest shown in Table 3, according to the results of the correlations (Table 1), the progenies that showed higher pulp content and relation between the soluble solids content and titratable acidity (TSS/TA) were not necessarily the ones with larger fruit size (weight, diameter and length of the fruit). The matrix 26, whose fruit produced more pulp content, was only on the fifth position in relation to the length of the fruit, and was among the top ten for the weight and diameter variables. Similarly, the matrix 11, in which the fruit was observed the highest ratio between soluble solids content and titratable acidity (TSS/TA) average, showed the second largest fruit length, and was also among the top ten progenies for weight and diameter of the fruit. However, the three best progenies classified in pulp content variable (26, 8 and 28) and in relation between the soluble solids and total titratable acidity $(11,14$ and 18$)$ were ordered beyond the twenty position for the variable corresponding (Table 3), in accordance to their correlations that were not significant both in progenies level as individuals level (Table 1).

In the simulation of the possible genetic gains to be achieved at the individuals level, the three fruit development variables (weight, diameter and length 
Table 3 - Estimations of genetic gains to be obtained at family level performed by SELEGEN program. Tabela 3 - Estimativas dos ganhos genéticos possiveis de serem obtidos em nivel de matrizes realizadas pelo programa SELEGEN.

\begin{tabular}{|c|c|c|c|c|c|c|c|c|c|c|c|c|c|c|c|}
\hline \multirow{3}{*}{$\frac{\text { Var. }}{\text { Mean }}$} & \multicolumn{3}{|c|}{ V1-FW (g) } & \multicolumn{3}{|c|}{ V2-DF $(\mathrm{cm})$} & \multicolumn{3}{|c|}{ V3-LF $(\mathrm{cm})$} & \multicolumn{3}{|c|}{ V7-PC (\%FW) } & \multicolumn{3}{|c|}{ V12-TSS/TTA } \\
\hline & & 302,75 & & & 7,76 & & & 9,57 & & & 24,05 & & & 17,22 & \\
\hline & Fam. & $\begin{array}{l}\text { New } \\
\text { Mean }\end{array}$ & $\begin{array}{l}\Delta \mathrm{g} \\
(\%)\end{array}$ & Fam. & $\begin{array}{l}\text { New } \\
\text { Mean }\end{array}$ & $\begin{array}{c}\Delta \mathrm{g} \\
(\%)\end{array}$ & Fam. & $\begin{array}{l}\text { New } \\
\text { Mean }\end{array}$ & $\begin{array}{c}\Delta \mathrm{g} \\
(\%)\end{array}$ & Fam. & $\begin{array}{l}\text { New } \\
\text { Mean }\end{array}$ & $\begin{array}{c}\Delta \mathrm{g} \\
(\%)\end{array}$ & Fam. & $\begin{array}{c}\text { New } \\
\text { Mean }\end{array}$ & $\begin{array}{l}\Delta \mathrm{g} \\
(\%)\end{array}$ \\
\hline 1 & 15 & 318,85 & 5,3 & 15 & 8,80 & 13,4 & 19 & 14,47 & 51,1 & 26 & 27,20 & 13,1 & 11 & 34,76 & 101,9 \\
\hline 2 & 23 & 317,60 & 4,9 & 23 & 8,79 & 13,3 & 11 & 13,27 & 38,6 & 8 & 27,08 & 12,6 & 14 & 31,96 & 85,6 \\
\hline 3 & 22 & 315,75 & 4,3 & 8 & 8,68 & 11,8 & 9 & 12,70 & 32,6 & 28 & 26,93 & 12,0 & 18 & 29,88 & 73,5 \\
\hline 4 & 4 & 314,65 & 3,9 & 28 & 8,57 & 10,5 & 22 & 12,33 & 28,8 & 27 & 26,79 & 11,4 & 22 & 27,98 & 62,5 \\
\hline 5 & 2 & 313,88 & 3,7 & 2 & 8,50 & 9,5 & 26 & 12,05 & 25,9 & 37 & 26,69 & 11,0 & 10 & 26,25 & 52,4 \\
\hline 6 & 11 & 313,34 & 3,5 & 29 & 8,44 & 8,8 & 33 & 11,83 & 23,6 & 17 & 26,61 & 10,6 & 21 & 24,95 & 44,9 \\
\hline 7 & 3 & 312,76 & 3,3 & 26 & 8,40 & 8,2 & 5 & 11,67 & 21,9 & 40 & 26,52 & 10,2 & 4 & 23,89 & 38,7 \\
\hline 8 & 29 & 312,23 & 3,1 & 11 & 8,36 & 7,7 & 4 & 11,54 & 20,5 & 39 & 26,43 & 9,9 & 17 & 23,09 & 34,1 \\
\hline 9 & 26 & 311,80 & 3,0 & 4 & 8,32 & 7,3 & 15 & 11,43 & 19,4 & 22 & 26,35 & 9,6 & 24 & 22,46 & 30,4 \\
\hline 10 & 13 & 311,43 & 2,9 & 3 & 8,29 & 6,9 & 3 & 11,33 & 18,3 & 32 & 26,28 & 9,2 & 35 & 21,95 & 27,5 \\
\hline 11 & 20 & 311,05 & 2,7 & 20 & 8,27 & 6,6 & 18 & 11,24 & 17,4 & 25 & 26,20 & 8,9 & 9 & 21,53 & 25,0 \\
\hline 12 & 28 & 310,69 & 2,6 & 21 & 8,25 & 6,3 & 32 & 11,16 & 16,5 & 23 & 26,13 & 8,7 & 25 & 21,18 & 23,0 \\
\hline 13 & 36 & 310,31 & 2,5 & 36 & 8,22 & 6,0 & 12 & 11,08 & 15,7 & 33 & 26,07 & 8,4 & 19 & 20,87 & 21,2 \\
\hline 14 & 32 & 309,96 & 2,4 & 5 & 8,20 & 5,7 & 2 & 11,00 & 14,9 & 5 & 26,00 & 8,1 & 5 & 20,60 & 19,6 \\
\hline 15 & 21 & 309,63 & 2,3 & 25 & 8,19 & 5,5 & 20 & 10,92 & 14,1 & 38 & 25,94 & 7,9 & 32 & 20,36 & 18,2 \\
\hline 16 & 9 & 309,32 & 2,2 & 27 & 8,17 & 5,3 & 36 & 10,85 & 13,3 & 35 & 25,88 & 7,6 & 36 & 20,15 & 17,0 \\
\hline 17 & 5 & 309,06 & 2,1 & 19 & 8,15 & 5,1 & 21 & 10,77 & 12,5 & 21 & 25,82 & 7,3 & 37 & 19,96 & 15,9 \\
\hline 18 & 18 & 308,80 & 2,0 & 10 & 8,14 & 4,9 & 29 & 10,70 & 11,8 & 31 & 25,76 & 7,1 & 30 & 19,78 & 14,9 \\
\hline 19 & 19 & 308,56 & 1,9 & 7 & 8,12 & 4,7 & 35 & 10,63 & 11,0 & 12 & 25,70 & 6,8 & 39 & 19,62 & 13,9 \\
\hline 20 & 8 & 308,34 & 1,8 & 13 & 8,11 & 4,5 & 31 & 10,56 & 10,3 & 10 & 25,64 & 6,6 & 7 & 19,46 & 13,0 \\
\hline 21 & 27 & 308,11 & 1,8 & 32 & 8,09 & 4,2 & 27 & 10,49 & 9,5 & 19 & 25,59 & 6,4 & 6 & 19,33 & 12,2 \\
\hline 22 & 25 & 307,88 & 1,7 & 35 & 8,07 & 4,0 & 23 & 10,42 & 8,5 & 2 & 25,54 & 6,2 & 26 & 19,20 & 11,5 \\
\hline 23 & 35 & 307,67 & 1,6 & 37 & 8,06 & 3,8 & 8 & 10,36 & 8,2 & 29 & 25,49 & 6,0 & 33 & 19,07 & 10,8 \\
\hline 24 & 12 & 307,45 & 1,6 & 12 & 8,04 & 3,6 & 7 & 10,31 & 7,6 & 13 & 25,44 & 5,8 & 16 & 18,95 & 10,1 \\
\hline 25 & 33 & 307,22 & 1,5 & 18 & 8,03 & 3,5 & 14 & 10,25 & 7,1 & 20 & 25,38 & 5,5 & 29 & 18,84 & 9,4 \\
\hline 26 & 7 & 307,01 & 1,4 & 30 & 8,02 & 3,3 & 16 & 10,20 & 6,6 & 30 & 25,33 & 5,3 & 31 & 18,74 & 8,8 \\
\hline 27 & 10 & 306,76 & 1,3 & 33 & 8,00 & 3,1 & 25 & 10,15 & 6,0 & 16 & 25,28 & 5,1 & 1 & 18,64 & 8,2 \\
\hline 28 & 31 & 306,51 & 1,2 & 31 & 7,99 & 2,9 & 28 & 10,10 & 5,5 & 14 & 25,22 & 4,9 & 27 & 18,54 & 7,7 \\
\hline 29 & 30 & 306,28 & 1,2 & 17 & 7,98 & 2,8 & 17 & 10,06 & 5,0 & 36 & 25,15 & 4,6 & 3 & 18,45 & 7,1 \\
\hline 30 & 37 & 306,06 & 1,1 & 22 & 7,96 & 2,6 & 24 & 10,01 & 4,6 & 1 & 25,09 & 4,3 & 20 & 18,36 & 6,6 \\
\hline 31 & 17 & 305,84 & 1,0 & 14 & 7,95 & 2,4 & 1 & 9,97 & 4,1 & 7 & 25,02 & 4,0 & 40 & 18,28 & 6,1 \\
\hline 32 & 40 & 305,61 & 0,9 & 16 & 7,93 & 2,2 & 37 & 9,92 & 3,6 & 18 & 24,93 & 3,6 & 38 & 18,19 & 5,6 \\
\hline 33 & 16 & 305,39 & 0,9 & 24 & 7,92 & 2,0 & 10 & 9,88 & 3,2 & 4 & 24,83 & 3,2 & 28 & 18,11 & 5,1 \\
\hline 34 & 1 & 305,08 & 0,8 & 40 & 7,90 & 1,8 & 30 & 9,84 & 2,8 & 9 & 24,72 & 2,8 & 8 & 18,03 & 4,7 \\
\hline 35 & 39 & 304,71 & 0,6 & 1 & 7,88 & 1,5 & 40 & 9,80 & 2,3 & 24 & 24,59 & 2,2 & 12 & 17,94 & 4,1 \\
\hline 36 & 14 & 304,34 & 0,5 & 9 & 7,86 & 1,3 & 13 & 9,76 & 1,9 & 15 & 24,47 & 1,7 & 2 & 17,85 & 3,6 \\
\hline 37 & 38 & 303,93 & 0,4 & 39 & 7,84 & 1,0 & 39 & 9,71 & 1,4 & 3 & 24,34 & 1,2 & 15 & 17,75 & 3,0 \\
\hline 38 & 24 & 303,38 & 0,2 & 38 & 7,80 & 0,5 & 6 & 9,65 & 0,8 & 11 & 24,20 & 0,6 & 23 & 17,53 & 1,8 \\
\hline 39 & 6 & 302,75 & 0,0 & 6 & 7,76 & 0,0 & 38 & 9,57 & 0,0 & 6 & 24,05 & 0,0 & 13 & 17,22 & 0.0 \\
\hline
\end{tabular}

Var.: Variables; Fam.: Family; $\Delta \mathrm{g}(\%)$ : Percentage of genetic gain compared to the mean.

of the fruit) showed positive gains through the indirect selection for one of the other two variables, according to the results of their correlations (Table 4). However, when selecting the best individuals within the progenies 15 and 23, which was the ones that showed the best results for weight and diameter of the fruit, it was verified negative genetic gains for the length of the fruit, although when selecting the best individuals of families 19 and 11, which were the ones that showed the highest fruit length (Table 3 ), it is possible to obtain positive genetic gains for the weight and diameter of fruit (Table 4).

In genetic gains simulations for the pulp content from indirect selection for fruits with greater development (weight, diameter and length of the fruit), it was not 
Table 4 - Simulation of genetic gains to be obtained in individuals and family levels through selection of ten better individuals for characters related with the development of the fruit (FW, DF and LF) and agrotechnological attributes (PC and relationship TSS/TTA).

Tabela 4 - Simulação dos ganhos genéticos possiveis de serem obtidos em nível de individuos e matrizes através da seleção dos dez melhores individuos para caracteres relacionados com o desenvolvimento do fruto (PF, DF and CF) e atributos agrotecnológicos (TP e relação STT/ATT).

\begin{tabular}{|c|c|c|c|c|c|}
\hline \multicolumn{6}{|c|}{ ORIGINAL VALUES OBSERVED IN THE EXPERIMENT } \\
\hline Variables & FW $(\mathrm{g})$ & $\mathrm{DF}(\mathrm{cm})$ & $\mathrm{LF}(\mathrm{cm})$ & $\mathrm{PC}(\% \mathrm{FW})$ & TSS/TTA \\
\hline Mean & 302,75 & 7,76 & 9,57 & 24,05 & 17,22 \\
\hline Ten better mean & 348,29 & 11,32 & 15,76 & 31,76 & 53,32 \\
\hline$\Delta \mathrm{g}(\%)$ ten better & 15,04 & 45,88 & 64,61 & 32,02 & 209,62 \\
\hline Ne ten better & 9 & 9 & 8 & 8 & 9 \\
\hline \multicolumn{6}{|c|}{ INDIRECT SELECTION FOR GREATER WEIGHT OF FRUITS } \\
\hline INDIVIDUALS LEVEL & \multicolumn{5}{|c|}{ *Present progenies: $2,3,4(2), 9(2), 11,15,35,39$} \\
\hline Ten best mean & - & 10,52 & 12,19 & 23,28 & 21,23 \\
\hline$\Delta \mathrm{g}(\%)$ ten best & - & 35,57 & 27,30 & $-3,22$ & 23,26 \\
\hline Indirect selection efficiency & - & 77,53 & 42,25 & $-10,06$ & 11,10 \\
\hline FAMILIES LEVEL & \multicolumn{5}{|c|}{ *Present progenies: $15(5), 23(5)$} \\
\hline Higher mean & 317,60 & 8,79 & 9,36 & 23,05 & 11,52 \\
\hline$\Delta \mathrm{g}(\%)$ higher & 4,90 & 13,27 & $-2,23$ & $-4,18$ & $-33,12$ \\
\hline Indirect selection efficiency & 32,60 & 28,93 & $-3,45$ & $-13,04$ & $-15,80$ \\
\hline \multicolumn{6}{|c|}{ INDIRECT SELECTION FOR LARGER DIAMETER OF FRUITS } \\
\hline INDIVIDUALS LEVEL & & Present pr & $2(2), 4($ & $8,9,37,3$ & \\
\hline Ten best mean & 337,81 & - & 10,97 & 22,94 & 22,66 \\
\hline$\Delta \mathrm{g}(\%)$ ten best & 11,58 & - & 14,61 & $-4,62$ & 31,55 \\
\hline Indirect selection efficiency & 76,99 & - & 22,61 & $-14,43$ & 15,05 \\
\hline FAMILIES LEVEL & \multicolumn{5}{|c|}{ *Present progenies: $15(5), 23(5)$} \\
\hline Higher mean & 317,60 & 8,79 & 9,36 & 23,05 & 11,52 \\
\hline$\Delta \mathrm{g}(\%)$ higher & 4,90 & 13,27 & $-2,23$ & $-4,18$ & $-33,12$ \\
\hline Indirect selection efficiency & 32,60 & 28,93 & $-3,45$ & $-13,04$ & $-15,80$ \\
\hline \multicolumn{6}{|c|}{ INDIRECT SELECTION FOR GREATER LENGTH OF FRUITS } \\
\hline INDIVIDUALS LEVEL & & Matrizes $\mathrm{p}$ & $3,4(3)$, & $15,19,26,3$ & \\
\hline Ten best mean & 335,56 & 9,41 & - & 24,04 & 19,52 \\
\hline$\Delta \mathrm{g}(\%)$ ten best & 10,84 & 21,29 & - & $-0,04$ & 13,32 \\
\hline Indirect selection efficiency & 72,07 & 46,40 & - & $-0,12$ & 6,35 \\
\hline FAMILIES LEVEL & \multicolumn{5}{|c|}{ *Present progenies: $19,11(9)$} \\
\hline Higher mean & 311,34 & 8,02 & 14,54 & 21,10 & 27,05 \\
\hline$\Delta \mathrm{g}(\%)$ higher & 2,84 & 3,37 & 51,86 & $-12,28$ & 57,08 \\
\hline Indirect selection efficiency & 18,86 & 7,34 & 80,26 & $-38,35$ & 27,23 \\
\hline \multicolumn{6}{|c|}{ INDIRECT SELECTION FOR SMALLER LENGTH OF FRUITS } \\
\hline INDIVIDUALS LEVEL & & $*$ Present 1 & $: 6,8,19$ & $(2), 39(3)$ & \\
\hline Ten best mean & 285,70 & 6,53 & 5,99 & 24,93 & 15,74 \\
\hline $\begin{array}{l}\Delta \mathrm{g}(\%) \text { ten best } \\
\text { Indirect selection efficiency }\end{array}$ & $\begin{array}{l}-5,63 \\
-37,43\end{array}$ & $\begin{array}{l}-15,82 \\
-34,48\end{array}$ & $\begin{array}{l}-37,39 \\
-57,87\end{array}$ & $\begin{array}{c}3,65 \\
11,40\end{array}$ & $\begin{array}{l}-8,63 \\
-4,12\end{array}$ \\
\hline FAMILIES LEVEL & \multicolumn{5}{|c|}{ *Present progenies: $6(3), 38(7)$} \\
\hline Lower mean & 291,20 & 6,63 & 7,21 & 23,17 & 13,64 \\
\hline$\Delta \mathrm{g}(\%)$ lower & $-3,82$ & $-14,59$ & $-24,71$ & $-3,69$ & $-20,80$ \\
\hline Indirect selection efficiency & $-25,38$ & $-31,79$ & $-38,25$ & $-11,52$ & $-9,92$ \\
\hline
\end{tabular}

*Present progenies: matrix identification and between parentheses the amount of fruits computed per matrix until it reached the sum of 10 units to perform the simulations.

Revista Árvore, Viçosa-MG, v.40, n.3, p.561-573, 2016 
possible to obtain genetic gains both at the individuals level as individuals within the best progenies (Table 4). The simulations involving the relation between the soluble solids content and the titratable acidity (TSS/ TA) indicate that it is possible to achieve positive genetic gains through indirect selection on all variables related to fruit development, ranging from $6.35 \%$ for the length of the fruit up to $15.05 \%$ for the fruit diameter. However, at the families' level, only the length of the fruit allowed the obtainment of positive genetic gains (27.23\%) for the TSS/TA.

Despite the correlation between the length of the fruit and the pulp content not being significant, they were negative and close to the $20 \%$ threshold in both families and individuals level, and for this reason was also verified the possibility of obtaining genetic gains by selecting both fruits as progenies that produce smaller fruit lengths (Table 4). Although these simulations estimate it is possible to increase the pulp content of more than $10 \%$ by indirect selection of fruits with smaller lengths, the possible reductions in the other variables related to fruit development (approximately $-25 \%$ for the weight of the fruit and $-32 \%$ for fruit diameter) do not compensate the genetic gains for pulp content.

\section{DISCUSSION}

Just as verified in this study, Farias Neto et al. (2004) and Silva et al. (2009) also reported positive and pronounced correlations between development variables of bacuri fruit. In their studies, the values of fruit level correlations between the variables diameter and length varied between $55 \%$ and $61 \%$, while in both the present study and in the one published by Silva et al. (2009) correlations were estimated above 90\% between the variables weight and fruit diameter. The marked correlation between the fruit development attributes described in different studies indicate probable common genetic control for these attributes (VIANA 2001), allowing to be performed in the field the indirect selection for the weight of the fruit from the diameter and length of fruits, because these variables are less subject to measurement errors outside the laboratory conditions.

Despite the correlations observed in this study indicate that fruits which develop more present a higher content of soluble solids, which is a property related to the taste of the fruit, the variables weight, diameter and length of the fruits were not significantly correlated with pulp content, what would be another very important property for consumers of the bacuri fruit. Differently, Farias Neto et al. (2004) found significant and negative correlations between pulp content and fruit development attributes, while Silva et al. (2009) estimated significant correlations between pulp content both with the weight of the fruit $\left(r_{x y=} 0.42\right)$ and with the diameter of the fruit $\left(r_{x y=} 0.47\right)$, and no significant correlations between soluble solids and fruit development variables. In this study, the pulp content also presented in the two levels of analysis significant and positive associations with the number of seeds per fruit and negative in relation to the thickness and peel content variables (accentuated on both levels), while in the studies by Neto et al. (2004) and Silva et al. (2009) the correlations between these variables did not show significant.

Regarding seed production, in the study of Silva et al. (2009), the number of seeds per fruit only showed significant correlation with the weight of the fruit $\left(r_{x y}=0.44\right)$ and with the diameter of the fruit $\left(r_{x y}=0.42\right)$, while Farias Neto et al. (2004) reported positive correlations ranging from $60 \%$ to $75 \%$ between the number of seeds per fruit and fruit development attributes, and negative ranging between $25 \%$ to $35 \%$ among variables related to the development of the fruit and pulp content. According to the botanical descriptions that indicate that the pulp surrounds the seed of bacuri fruit, the correlations found in this study involving the pulp content indicate that fruits that grow thinner peel and with more seeds are able to produce more pulp content, with the condition that these seeds do not represent a large portion of the fruit. However, the number of seeds per fruit showed $\mathrm{CVe} \%$ above $20 \%$ both in this study and in those by Neto et al. (2004) and Silva et al. (2009), indicating that in addition to not being simple its evaluation, this variable is subject to random adverse variations and therefore it is little recommended for use in the indirect selection made in order to increase the pulp content of the bacuri fruit.

The most important function of heritability in the genetic study of the metric character is its predictive role expressing the reliability of the correspondence between the phenotypic and the genetic values (FALCONER 1981; VENCOVSKY; BARRIGA 1992), while $\mathrm{CVe} \%$ values below 0.15 indicate that the experimental structures were well defined in experiments involving perennial species (VENCOVSKY; BARRIGA 1992). In this study, it were observed $C V e \%$ below $15 \%$ and

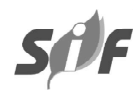

Revista Árvore, Viçosa-MG, v.40, n.3, p.561-573, 2016 
heritability close to $30 \%$ for pulp, peel and soluble solids contents, indicating that in this experimental condition it is possible to obtain good genetic gains for these variables. Other authors estimated significantly higher repeatability coefficient in relation to the individual heritability values obtained in this study for the pulp and soluble solids contents, being estimated by Silva et al. (2009) of 0.4686 to pulp content and 0.9425 for soluble solids content (both with Cve \% below 15\%), while Farias Neto et al. (2004) estimated repeatability coefficients of 0.6592 for pulp content.

Among the variables related to the growth of the fruit, only fruit length showed selection potential, presenting individual heritability in the narrow sense of $15 \%$ and Cve $\%$ below $10 \%$. In the study by Silva et al. (2009), growth parameters (weight, diameter and length of the fruit) showed Cve \% below $15 \%$ and repeatability coefficients between $40 \%$ and $50 \%$, while Farias Neto et al. (2004) found CVe \% below $15 \%$ and repeatability coefficients also around $70 \%$ and $80 \%$ for the variables diameter and length of the fruit, and repeatability coefficient of $43 \%$ for the weight of fruit with CVe \% exceeding 37\%.

Comparing the low heritability values estimated in this study with the high values of repeatability coefficients reported in the studies by Farias Neto et al. (2004) and Silva et al. (2009), it is concluded that this marked difference is inherent in both the model used in their analysis, which did not considered the existence of experimental designs, as the evaluation of a relatively small set of samples in the form of unbalanced data. Farias Neto et al. (2004) evaluated thirteen progenies located in a natural population situated in the state of Maranhão, in which were measured parameters of ten fruits per progenie. In his analysis, Farias Neto et al. (2004) indicated that it is necessary up to ten measurements to predict with $95 \%$ reliability the actual value of the variables length and diameter of the fruit, peel thickness, pulp and peel content, and over 20 measurements to obtain the real value of the variables weight of the fruit and number of seeds with the same reliability. On the other hand, Silva et al. (2009) evaluated in their study eight fruits only from each of the six progenies present in an area located in the state of Maranhão. In that analyzes, whose author evaluated a smaller number of samples, it was estimated that, with the exception of the variables titratable acidity and soluble solids content, over 20 measurements would be needed to obtain the actual value of all the other variables with $95 \%$ reliability.

As described by Maia et al. (2011), the selection based on tests of half-siblings population's progenies in fruit species tends to better exploit the additive genetic variance when performing the selection both between and within families, as it was accomplished in this study in the simulation of the genetic gains by indirect selection for agro-technological and fruit development variables (Table 4). The high repeatability estimates obtained for different variables are indicative of the existence of wide phenotypic variability in the germplasm evaluated, which is a desirable situation in an experimental area composed of progenies collected in a large area of natural occurrence of the species, which aims to ensure the existence of wide variability to support the early stages of the improvement program of bacuri tree (CRUZ et al. 2007). Based on these results, it is believed that the components of variance and correlations found in this study, in which was assessed a total of 210 bacuri fruit, coming from 39 progenies that had at least 10 fruits evaluated, will provide more credible genetic gains against the estimated, for selection within the experimental conditions in which these progenies are.

Despite the indirect selection simulations indicate that larger fruits do not provide genetic gains for the pulp content, the selection of individuals with smaller fruit lengths presented the possibility of obtaining positive genetic gains for the pulp content above $10 \%$ $(11.4 \%)$. However, the selection of fruits with smaller lengths provides negative genetic gains for the relation between the soluble solids content and titratable acidity (TSS/TA) and for the other variables related to the fruit development (weight and diameter of the fruit). For this reason the selection of fruits with shorter length is not interesting for the genetic enhancement of this species. As for the relation between the soluble solids content and total titratable acidity (TSS/TA), it was verified the possibility of obtaining genetic gains at the individuals level through the three variables related to the development of the fruit, but at the progenies level, which is where the selection will be made, these gains are possible only through the indirect selection for the fruit length.

Considering only the variables of weight, diameter and length of the fruit, which are related to their development, the simulations at the individuals level indicate that it is possible to obtain genetic gains for 
the other two through the indirect selection of any of them, while in family level it was not possible to obtain gains for the fruit length through the selection of progenies that produce fruits with greater weight and diameter. Thus, both at progenies as fruits levels, the variable fruit length appears as the most suitable to carry out the combined selection aiming fruit with larger size (PIRES et al. 1996), because among the variables possible to be evaluated in the field, it was the one that presented, both in this and in other studies, similar values in the correlations with the variables weight and diameter of the fruit, besides presenting higher heritability than other variables because it is less influenced by the environment under the conditions evaluated in this study.

\section{CONCLUSIONS}

The variables associated with the fruit development are strongly correlated with the productivity of the bacuri tree, but according to the obtained results, except for the variable fruit length, the fruit variables weight and diameter presented zero heritability, mainly due to strong influence of the experimental structures acting in conjunction with the wide variability present in the experimental area. Given these results, the variable fruit length appears more interesting for indirect selection in order to increase both the size of the fruit as the relation between soluble solids content and total acidity (TSS/TA). Additionally, the results obtained in this experiment indicate that as in every wild species enhancement program, there will hardly be possible to select genetic material with the double aptitude for pulp content and oil derived from the seeds in the early stages of bacuri improvement program.

Thus, the enhancement of bacuri from the progenies present in the evaluated experimental area must be achieved through recombination of superior existing genotypes in the improvement program of this species, using controlled pollination techniques or the management of the experimental structures by eliminating genotypes with lower agrotechnological properties, thereby maximizing the cross between superior genotypes and the pyramiding of genes related to variables of interest. Following this reasoning, it is concluded that special attention should be allocated to the matrix 26 , which possess good attributes of fruit size and pulp yield, also to the progenies 4, 11 and 22 which have good attributes of fruit size and the relation between the soluble solids content and the titratable acidity (TSS/TA), and to matrix 17, which present good pulp yield and TSS/TA.

\section{REFERENCES}

AGUIAR, L.P.; FIGUEIREDO, R.W.; ALVES; R.E.; MAIA, G.A.; SOUZA, V.A.B. Caracterização física e físico-química de frutos de diferentes genótipos de bacurizeiro (Platonia insignis Mart.).

Ciência e Tecnologia de Alimentos, v.28, p.423-428, 2008.

BENJAMINI, Y.; HOCHBERG, Y. Controlling the false discovery rate: a practical and powerful approach to multiple testing. Journal of the Royal Statistical Society, Series B v.57, n.1, p.289-300, 1995.

CARVALHO, J.E.U.; MÜLLER, C.H.; NASCIMENTO, W.M.O. Métodos de propagação do bacurizeiro (Platonia insignis Mart.). Belém: Embrapa Amazônia Oriental, 2002. 12 p. (Circular Técnica, 30).

CARVALHO, J.E.U.; NAZARÉ, R.F.R.; NASCIMENTO, W.M.O. Características físicas e físico-químicas de um tipo de bacuri (Platonia insignis Mart.) com rendimento industrial superior. Revista Brasileira de Fruticultura, v.25, p.326-328, 2003.

CARVALHO, J.E.U.; MÜLLER, C.H. Propagação do bacurizeiro. In: LIMA, M.C. (Org.). Bacurizeiro: agrobiodiversidade. São Luís: IICA, 2007. p.29-46.

CHITARRA, A.B.; CHITARRA, M.I.F. Póscolheita de frutos e hortaliças: fisiologia e manuseio. $2^{\text {a }}$.ed. Lavras: UFLA, 2005. 785p.

GRUZ, C.D.; REGAZZI, A.J.; CARNEIRO, P.C.S. Modelos biométricos aplicados ao melhoramento genético. Viçosa, MG: Universidade Federal de Viçosa, 2004. 480p.

CRUZ, C.D.; MOURA, M.C.C.L.; FERREIRA, A.; MASCARENHAS, K.M.; ARAÚJO, J.R.G.; MARTINS, M.R. Utilização da biometria no melhoramento genético do bacurizeiro. In: LIMA, M.C. (Org.). Bacurizeiro: agrobiodiversidade. São Luís: IICA, 2007. p.101-155.

Revista Árvore, Viçosa-MG, v.40, n.3, p.561-573, 2016 
SILVA, V.K.L.; FIGUEIREDO, R.W.; BRITO, E.S.; MAIA, G.A.; SOUZA, P.H.M.; FIGUEIREDO, E.A.T. Estabilidade da polpa do bacuri (Platonia insignis Mart.) congelada por 12 meses.

Ciência e Agrotecnologia, v. 34, n.5, p.1293-1300, 2010.

DUARTE, J.B.; VENCOVSKY, R. Estimação e predição por modelo linear misto com ênfase na ordenação de médias de tratamentos genéticos.

Scientia Agricola, v. 58, n.1, p.109-117, 2001.

FALCONER, D.S. Introdução à genética quantitativa. Viçosa, MG: Universidade Federal de Viçosa, 1981. 279 p.

FONTENELE, M.A.; FIGUEIREDO, R.W.; MAIA, G.A.; ALVES, R.E.; SOUZA, P.H.M.; SOUZA, V.A.B. Conservação Pós-Colheita de Bacuri (Platonia insignis Mart.) sob Refrigeração e Embalado em PVC. Revista Ceres, v.57, p.292-296, 2010.

FRAZÃO, D.A.C.; HOMMA, A.K.O. Fruticultura: uma alternativa sustentável para ao agronegócio na Amazônia. In: FRAZÃO, D.A.C.; HOMMA, A.K.O.; VIÉGAS, I.J.M. (Ed.). Contribuição ao desenvolvimento da fruticultura na Amazônia. Belém: Embrapa Amazônia Oriental, 2006. p.29-42.

MAIA, M. C. C.; RESENDE, M. D. V.; OLIVEIRA, L. C.; ALVES, R. M.; SILVA FILHO, J. L.; ROCHA, M. M.; CAVALCANTI, J. J. V.; RONCATO, G. Análise genética de família de meios-irmãos de cupuaçuzeiro. Pesquisa

Florestal Brasileira, v.31, p.123-130, 2011.

MATOS, G.B.; HOMMA, A.K.O.; MENEZES, A.J.E.A. Levantamento Socioeconômico do bacurizeiro (Platonia insignis Mart.) nativos das Mesorregiões do Nordeste Paraense e do Marajó. Belém: Embrapa Amazônia Oriental, 2009. 81p. (Documentos, 351).

MAUES, M.M.; VENTURIERI, G.C.; SOUZA, L.A.; NAKAMURA, J.; MIYANAGA, R. Identificação e técnicas de criação de polinizadores de espécies vegetais de importância econômica no estado do Pará. In: Geração de tecnologia agroindustrial para o desenvolvimento do Trópico Úmido. Belém: Embrapa-CPATU: IICA, 1996. p.17-55.
MORAES, V.H.F.; MÜLLER, C.H; SOUZA, A.G.C.; COHEN ANTÔNIO, I. Native fruit species of economic potential from the brazilian Amazon. Angewandte Botanik, v.68, p.47-52, 1994.

NASCIMENTO, W.M.O.; CARVALHO, J.E.U.; MÜLLER, C.H. Ocorrência e distribuição geográfica do bacurizeiro. Revista Brasileira de Fruticultura, v.29, p.657-660, 2007.

NAZARÉ, R.F.R. Produtos agroindustriais de bacuri, cupuaçu, graviola e açaí, desenvolvidos pela Embrapa Amazônia Oriental. Belém: Embrapa Amazônia Oriental, 2000. 27p. (Documentos, 41).

FARIAS NETO, J.T.F.; CARVALHO, J.U.; MULLER, C.H. Estimativas de correlação e repetibilidade para caracteres do fruto do bacurizeiro. Ciência e Agrotecnologia, v.28, n.2, p.300-305, 2004.

PIEPHO, H.P.; MÖHRING, J.; MELCHINGER, A.E.; BÜCHSE, A. BLUP for phenotipic selection in plant breeding and variety test. Euphytica, v.161, n.2, p.209-228, 2007.

PIRES, I.E.; CRUZ, C.D.; BORGES, R.C.G.; REGAZZI, A.J. Índice de seleção combinada aplicado ao melhoramento genético de Eucalyptus spp. Revista Árvore, v.20, n.2, p.191-197, 1996.

RESENDE, M.D.V. Software SELEGEN REML/BLUP. Colombo: Embrapa Florestas, 2002.67p. (Documentos, 77).

RESENDE, M.D.V. Matemática e estatística na análise de experimentos e no melhoramento genético. Colombo: Embrapa, 2007.561p.

RESENDE, M.D.V.; DUARTE, J.B. Precisão e controle de qualidade em experimentos de avaliação de cultivares. Pesquisa

Agropecuária Tropical, v.37, n.3, p.182-194, 2007.

ROGEZ, H.; BUXANT, R.; MIGNOLET, E.; SOUZA, J.N.S.; SILVA, E.M.; LARONDELLE, Y. Chemical composition of the pulp of three typical Amazonian fruits: araça-boi (Eugenia stipitata), bacuri (Platonia insignis) and cupuaçu (Theobroma 
grandiflorum). European Food Research and Technology, v.218, p.380-384, 2004.

SOARES, L.C.; MAIA FILHO, A.L.M.; ARAÚJO, K.S.; SANTOS, I.M.S.P.; COSTA JÚNIOR, J.S.; SAFFI, J. Estudo histológico da cicatrização de feridas cutâneas utilizando a banha de bacuri (Platonia insignis Mart.). Conscientia e Saúde, v.9, n.4, p.575-581, 2010.

SHANLEY, P. As the forest falls: the changing use, ecology and value of non-timber forest resources for caboclo communities in eastern Amazonia. 2000. 214f. Tese (Doutorado em Manejo de Recursos Naturais) - The Durrel Institute of Conservation and Ecology, The University of Kent, Cantebury, 2000.

SILVA, R.G.; CHAVES, M.C.L.; ARNHOLD, E.; CRUZ, C.D. Repetibilidade e correlações fenotípicas de caracteres do fruto de bacuri no Estado do Maranhão. Acta Scientiarum Agronomy, v.31, n.4, p.587-591, 2009.

SILVA, V.K.L.; FIGUEIREDO, R.W.; BRITO, E.S.; MAIA, G.A.; SOUZA, P.H.M.; FIGUEIREDO, E.A.T. Stability of the bacuri pulp (Platonia insignis Mart.) frozen for 12 months. Ciência e
Agrotecnologia, v.34, n.5, p.1293-1300, 2010.

SOUZA, V.A.B.; VASCONCELOS, L.F.L.; ARAÚJO, E.C.E.; ALVES, R.E. O bacurizeiro (Platonia insignis Mart.). Jaboticabal: Funep, 2000.72p. (Série frutas nativas, 11).

SOUZA, V.A.B. de S.; ARAÚJO, E.C.E.; VASCONCELOS, L.F.L.; LIMA, P.S.C. Variabilidade de características físicas e químicas de frutos de germoplasma de Bacuri da região Meio-Norte do Brasil. Revista Brasileira de Fruticultura, v.23, n. 3, p.677-683, 2001.

SOUZA, V.A.B.; VASCONCELOS, L.F.L.; ARAÚJO, E.C.E. Recursos genéticos do bacurizeiro na região Meio Norte do Brasil. In: LIMA, M.C. (Org.). Bacurizeiro: agrobiodiversidade. São Luís: IICA, 2007. p.65-101.

VENCOVSKY, R.; BARRIGA, P. Genética biométrica no fitomelhoramento. Ribeirão Preto: Sociedade Brasileira de Genética, 1992. 496 p.

VIANA, J.M.S. Genetic correlations in family structured populations. Revista Árvore, v.25, n.1. p.97-103, 2001. 